\title{
Kajian Kritis terhadap Epistemologi Ilmu: Konsep Hypothetic-Deductive, Verifikasi dan Falsifikasi
}

\author{
Andi Saefulloh Anwar ${ }^{1}$, Nanat Fatah Natsir ${ }^{2}$, Erni Haryanti ${ }^{3}$ \\ 1,2,3Universitas Islam Negeri Sunan Gunung Djati Bandung, Indonesia \\ E-mail: andisaefullohanwar@gmail.com,nanatfatahnatsir@uinsgd.ac.id,erni_hk@uinsgd.ac.id
}

\begin{abstract}
Article Info
Article History

Received: 2021-12-27

Revised: 2022-01-22

Published: 2022-02-01
\end{abstract}

Keywords:

Epistemology;

Hypothetic-deductive;

Verification;

Falsification.

\begin{abstract}
This study describes a critical study of the epistemology of science: hypotheticdeductive concepts, leverage, and falsification. The method used in this study uses a method or approach to literature (library research), that the study of literature or literature can be interpreted as an evaluation of activities related to the methods of collecting library data, reading and taking notes, and processing research materials. The results of this study indicate that epistemology is knowledge about systematic knowledge which is one of the branches of philosophy that discusses the occurrence of knowledge, sources of knowledge, origins of knowledge, methods or ways of obtaining knowledge, validity and truth of knowledge. logico, hypotetico and levers. HypotheticoDeductive is a method that involves hypothesis testing in which the hypothesis is deduced from other hypotheses with a higher level of abstraction or conceptual formulation. After submitting the hypothesis, the next step is to verify it as empirically proving the truth. But Popper argues that a truth is not determined through justification (verification), but through the denial of propositions built by science itself (falsification).
\end{abstract}

\begin{tabular}{l}
\hline Artikel Info \\
\hline Sejarah Artikel \\
Diterima: 2021-12-27 \\
Direvisi: 2022-01-22 \\
Dipublikasi: 2022-02-01
\end{tabular}

Kata kunci:

Epistemologi;

Hypothetic-deductive;

Verifikasi;

Falsifikasi.

\begin{abstract}
Abstrak
Penelitian ini menjelaskan tentang kajian kritis terhadap epistemologi ilmu: konsep hypothetic-deductive, verifikasi, dan falsifikasi. Metode yang digunakan dalam kajian ini menggunakan metode atau pendekatan kepustakaan (library research), bahwa studi pustaka atau kepustakaan dapat diartikan sebagai serangkaian kegiatan yang berkenaan dengan metode pengumpulan data pustaka, membaca dan mencatat serta mengolah bahan penelitian. Hasil penelitian ini menunjukkan bahwa epistemologi adalah pengetahuan sistematik mengenai pengetahuan yang merupakan salah satu cabang filsafat yang membahas tentang terjadinya pengetahuan, sumber pengetahuan, asal mula pengetahuan, metode atau cara memperoleh pengetahuan, validitas dan kebenaran pengetahuan, untuk memperoleh pengetahuan yang benar maka kriterianya harus berdasarkan logico, hypotetico dan verifikasi. Hypothetico-Deductive adalah suatu metode yang melibatkan pengujian hipotesis dimana hipotesis tersebut dideduksi dari hipotesis lain yang tingkat abstraksinya atau perumusan konseptualnya lebih tinggi. Setelah mengajukan hipotesis maka tahap selanjutnya adalah melakukan verifikasi sebagai pembuktian kebenaran secara empiris. Namun Popper berpendapat bahwa kebenaran suatu ilmu bukan ditentukan melalui pembenaran (verifikasi), melainkan melalui upaya penyangkalan terhadap proposisi yang dibangun oleh ilmu itu sendiri (falsifikasi).
\end{abstract}

\section{PENDAHULUAN}

Tiga landasan ilmu pengetahuan atau yang sering disebut dengan tiga tiang peyangga ilmu pengetahuan dalam kajian filsafat ilmu terdiri atas ontologi, epistimologi dan aksiologi. Liek Wilardjo dalam (Hasbi, 2021) menambahkan satu landasan lagi yang disebut dengan teleologis yang biasanya digabungkan dengan aksiologis, ketiga unsur ini merupakan tolok ukur dalam membangun The Body of Knowledge. Bangunan keilmuan yang ditopang tiga tiang peyangga ini menjadi prasyarat mutlak jika mengupas hubungan sinergi antara filsafat ilmu dengan metodologi penelitian, secara aplikasi pola peng- gunaan tiga tiang peyangga ini dalam riset utamanya dalam rancangan penelitian akan terwujud pada tataran ontologis akan tercermin pada latar belakang penelitian, rumusan dan batasan masalah, termasuk didalamnya penelitian terdahulu maupun kajian pustaka, adapun tataran epistimologi terwujudkan dalam metode penelitian dan pada ataran aksiologi maupun teleologis berwujud untuk tujuan dan manfaat penelitian. Tiga ranah ini sesungguhnya menjadi kata kunci landasan filosofis dalam riset.

Salah satu tiang penopang dalam bangunan ilmu pengetahuan adalah epistimologi. Epistimologi merupakan asas mengenai cara bagaimana 
materi pengetahuan diperoleh dan disusun menjadi suatu tubuh pengetahuan, Epistimologi membahas secara mendalam segenap proses yang terlibat dalam usaha untuk memperoleh pengetahuan. Epistimologi merupakan teori pengetahuan yang diperoleh melalui proses metode keilmuan dan sah disebut sebagai keilmuan, dengan epistimologi maka hakikat keilmuan akan ditentukan oleh cara berfikir yang dilakukan dengan sifat terbuka dan menjunjung tinggi kebenaran di atas segala-galanya.

Konsep epistimologi secara eksplisit dapat dikaji dari penerapan metode ilmiah. Makna metode ilmiah dalam penerapan metodologis merupakan prosedur yang mencakup berbagai tindakan pikiran, pola kerja, cara teknis dan tata langkah untuk memperoleh pengetahuan yang baru atau mengembangkan pengetahuan yang ada (Supriani, 2022). Langkah-langkah semakin bervariasi dalam ilmu pengetahuan tergantung pada bidang spesialisasinya (Fatira, 2021), pada dasarnya metode ilmiah merupakan cara ilmu memperoleh dan menyusun tubuh pengetahuannya berdasarkan kerangka pemikiran yang bersifat logis dengan argumentasi yang bersifat konsisten dengan pengetahuan sebelumnya yang telah berhasil disusun, menjabarkan hipotesis yang merupakan deduksi dari kerangka pemikiran tersebut dan melakukan verfikasi terhadap hipotesis termaksud untuk menguji kebenaran pernyataan secara factual (Darmawan, 2021). Ketiga hal di atas secara akronim disebut dengan logico hypotetico verificative-deducto hypothetico verificative, kerangka pemikiran yang logis adalah argumentasi yang bersifat rasional dalam mengembangkan penjelasan terhadap fenomena alam (Arifudin, 2020). Verifikasi secara empiris berarti evaluasi secara objektif dari suatu pernyataan hipotesis terhadap kenyataan faktual. Verfikasi ini berarti bahwa ilmu terbuka untuk kebenaran lain selain yang terkandung dalam hipotesis (mungkin fakta menolak hipotesis). Demikian juga verifikasi faktual membuka diri atas kritik terhadap kerangka pemikiran yang mendasari pengajuan hipotesis, kebenaran ilmiah dengan keterbukaan terhadap kebenaran baru mempunyai sifat pragmatis yang prosesnya berulang berdasarkan cara berfikir kritis.

\section{METODE PENELITIAN}

Sesuai dengan karakteristik masalah yang diangkat dalam penelitan ini maka menggunakan Metode Riset kualitatif yaitu menekankan analisanya pada data deskriptif berupa kata-kata tertulis yang diamati, pendekatan kualitatif penulis gunakan untuk menganalisis kritis terhadap epistemologi ilmu: konsep hypotheticdeductive, verifikasi, dan falsifikasi. Maka dengan sendirinya penganalisaan data ini lebih difokuskan pada Penelitian Kepustakaan (Library Research) yakni dengan membaca, menelaah dan mengkaji buku-buku dan sumber tulisan yang erat kaitannya dengan masalah yang dibahas, metode yang digunakan dalam kajian ini menggunakan metode atau pendekatan kepustakaan (library research), menurut Zed dalam (Rahayu, 2020) bahwa studi pustaka atau kepustakaan dapat diartikan sebagai serangkaian kegiatan yang berkenaan dengan metode pengumpulan data pustaka, membaca dan mencatat serta mengolah bahan penelitian.

Jenis penelitian ini adalah penelitian kualitatif, menurut Ibnu dalam (Arifudin, 2021) penelitian kualitatif adalah suatu penelitian yang datanya dinyatakan dalam bentuk verbal dan dianalisis tanpa menggunakan teknik statistik, berdasarkan beberapa definisi penelitian kualitatif di atas dapat disimpulkan bahwa penelitian kualitatif adalah suatu penelitian yang datanya dinyatakan dalam bentuk verbal, tidak menggunakan angka dan analisisnya tanpa menggunakan teknik statistik.

1. Objek Penelitian

Dalam penelitian ini objek penelitian terdiri dari 2 (dua) yaitu objek formal dan objek material (Arifudin, 2018). Objek formal dalam penelitian ini berupa data yaitu data yang berhubungan dengan tinjauan kritis kritis terhadap epistemologi ilmu: konsep hypothe-tic-deductive, verifikasi dan falsifikasi. Sedangkan objek materialnya berupa sumber data, dalam hal ini adalah tinjauan kritis kritis terhadap epistemologi ilmu: konsep hypothetic-deductive, verifikasi, dan falsifikasi.

2. Waktu Penelitian

Penelitian ini dilaksanakan pada bulan Oktober sampai dengan Desember tahun 2021.

3. Teknik Pengumpulan Data

Pengumpulan data yang dilakukan dengan menggunakan teknik dokumentasi yaitu mengadakan survey bahan kepustakaan untuk mengumpulkan bahan-bahan dan studi literatur yakni mempelajari bahan-bahan yang berkaitan dengan objek penelitian. Teknik pengumpulan data menurut (Bahri, 2021) mengemukakan bahwa merupakan langkah yang paling strategis dalam penelitian karena tujuan untama dari penelitian adalah mendapatkan data. Terdapat beberapa cara atau 
teknik dalam mengumpulkan data, diantaranya adalah observasi dan dokumentasi. Sumber data yang digunakan dalam penelitian ini mencakup data primer dan sekunder. Menurut (Hanafiah, 2021) bahwa data primer adalah data yang dikumpulkan langsung dari individu-individu yang diselidiki atau data tangan pertama, sedangkan data sekunder adalah data yang ada dalam pustaka-pustaka. Data primer dalam penelitian ini adalah bukubuku terkait tinjauan kritis kritis terhadap epistemologi ilmu: konsep hypotheticdeductive, verifikasi dan falsifikasi, kemudian data sekunder didapatkan dari jurnal-jurnal baik nasional maupun internasional.

4. Alat Pengumpulan Data

Dalam penelitian ini, penulis akan menggunakan metode dokumentasi sebagai alat untuk pengumpul data karena penelitian ini adalah penelitian kepustakaan, dengan kata lain menurut (Tanjung, 2022) bahwa teknik ini digunakan untuk menghimpun data-data dari sumber primer maupun sekunder.

5. Teknik Analisis Data

Analisis data tidak saja dilakukan setelah data terkumpul, tetapi sejak tahap pengumpulan data proses analisis telah dilakukan. Penulis menggunakan strategi analisis "kualitatif", strategi ini dimaksudkan bahwa analisis bertolak dari data-data dan bermuara pada kesimpulan-kesimpulan umum, berdasarkan pada strategi analisis data ini dalam rangka membentuk kesimpulan-kesimpulan umum analisis dapat dilakukan menggunakan kerangka pikir "induktif". Menurut (Sugiyono, 2015) bahwa metode pembahasan menggunakan metode deskriptif-analisis, yaitu menjelaskan serta mengelaborasi ide-ide utama yang berkenaan dengan topik yang dibahas. Kemudian menyajikannya secara kritis melalui sumber-sumber pustaka primer maupun skunder yang berkaitan dengan tema.

6. Prosedur Penelitian

Data pada penelitian ini dicatat, dipilih dan kemudian diklasifikasikan sesuai dengan kategori yang ada. Pendekatan yang digunakan adalah pendekatan deskriptif analitis. Menurut (Mayasari, 2021) bahwa deskriptif analitis (descriptive of analyze research), yaitu pencarian berupa fakta, hasil dari ide pemikiran seseorang melalui cara mencari, menganalisis, membuat interpretasi serta melakukan generalisasi terhadap hasil penelitian yang dilakukan. Prosedur penelitian ini menurut (Nasser, 2021) adalah untuk meng- hasilkan data deskriptif yang berupa data tertulis setelah melakukan analisis pemikiran (content analyze) dari suatu teks. Setelah penulis mengumpulkan bahan-bahan yang berhubungan dengan masalah yang akan di bahas dalam penelitian ini, kemudian penulis menganalisis dan menarasikan untuk diambil kesimpulan.

\section{HASIL DAN PEMBAHASAN}

Dalam pembahasan ini akan dibahas tentang Konsep Hypothetic-Deductive, Konsep Verifikasi, dan Konsep Falsifikasi.

\section{Konsep Hypothetic-Deductive}

Penalaran Deduktif adalah suatu kerangka atau cara berfikir yang bertolak dari sebuah asumsi atau pernyataan yang bersifat umum untuk mencapai sebuah kesimpulan yang bermakna lebih khusus. Penalaran Deductive sering pula diartikan dengan istilah logika minor dikarenakan memperdalami dasardasar penyesuaian dalam pemikiran dengan hukum, rumus dan patokan-patokan tertentu (Mundiri, 2000). Pola penarikan kesimpulan dalam metode deduktif merujuk pada pola berfikir yang disebut silogisme yaitu bermula dari dua pernyataan atau lebih dengan sebuah kesimpulan yang mana kedua pernyataan tersebut sering disebut sebagai premis minor dan premis mayor serta selalu diikuti oleh penyimpulan yang diperoleh melalui penalaran dari kedua premis tersebut. Namun kesimpulan di sini hanya bernilai benar jika kedua premis dan cara yang digunakan juga benar, serta hasilnya juga menunjukkan koherensi data tersebut (Jujun, 2007).

Lebih jauh lagi deduksi sering lahir dari sebuah persangkaan mayoritas orang, sehingga hampir bisa dikatakan bahwa setiap keputusan adalah deduksi dan setiap deduksi diambil dari suatu generalisasi yang berupa generalisasi induktif yang berdasar hal-hal khusus yang diamati, generalisasi ini terjadi karena adanya kesalahan dalam penafsiran terhadap bukti yang ada, generalisasi induktif sering terjadi dari banyaknya tumpuan pada pengamatan terhadap hal-hal khusus yang kenyataanya tidak demikian, seperti halnya kesalahan dokter dalam mendiagnosis penyakit pasien hal ini terjadi karena tandatandanya sama namun bisa jadi ada penyakit lain dengan tanda-tanda seperti itu ataupun kasus polisi yang menyelidiki barang bukti di tempat tindakan kriminal. 
Kelebihan model ini adalah terletak pada faktor kebutuhan fokus yang intens dalam menganalisa suatu pengertian dari segi materinya, sehingga penggunaan waktu bisa lebih efisien, bahkan dari segi lain keterampilan yang digunakan bisa tersusun lebih rapi, hal ini bisa terjadi karena poin-poin yang ingin dicapai sudah jelas. Terlebih pendekatan ini sesuai untuk digunakan dalam proses pembelajaran, seperti halnya guru memberikan penerangan sebelum memulai pembelajaran. Selain itu pada deduksi, kesimpulannya merupakan suatu konsekuensi logis dari premispremisnya. Sehingga pada suatu penalaran yang baik, kesimpulan dapat menjadi benar manakala premis-premisnya benar (Siregar, 2021). Adapun kelemahannya terletak pada aktifitas penarikan kesimpulan yang dibatasi pada ruang lingkup tertentu. Serta jika salah satu dari kedua premisnya, atau bahkan keduanya salah maka kesimpulan yang didapat berdasarkan premis tersebut akan salah pula. Kelemahan lainnya adalah kesimpulan yang diambil berdasarkan logika deduktif tak mungkin lebih luas dari premis awalnya, sehingga sulit diperoleh kemajuan ilmu pengetahuan jika hanya mengandalkan logika deduktif.

Hypothetico-Deductive adalah suatu metode yang melibatkan pengujian hipotesis dimana hipotesis tersebut dideduksi dari hipotesis lain yang tingkat abstraksinya, atau perumusan konseptualnya, lebih tinggi metode tersebut merupakan metode atau pendekatan standar dalam pradigma klasik. Oleh karena itu pula kriteria yang dipergunakan untuk menilai kualitas suatu penelitian (goodness criteria) sepenuhnya bertolak dari paradigma klasik atau perspektif postpositivism. Pengertian hypothetico-deductive method merupakan rangkaian langkahlangkah penelitian yang didasarkan atas sistem logika deduktif, berbeda dengan penelitian yang didasarkan pada sistem logika induktif (grounded theory/research), maka dalam hypothetico deductive method, suatu penelitian empirik diawali oleh suatu proses deduktif yang berawal dari pembentukan kerangka teori, untuk melahirkan hipotesishipotesis sebagai jawaban sementara bagi masalah penelitian yang lebih lanjut akan diuji (melalui pencarian supporting empirical evidence) melalui suatu perangkat metodologi tertentu.
2. Konsep Verifikasi

Para filsuf pada 'kelompok' Lingkaran Wina pada umumnya mencurahkan perhatiannya untuk mencari garis pemisah antara pernyataan yang bermakna (meaningful) dan pernyataan yang tidak bermakna (meaningless) berdasarkan kemungkinan untuk diverifikasi. Artinya jika suatu pernyataan dapat diverifikasi maka ia berarti bermakna, sebaliknya jika tidak dapat diverifikasi berarti tidak bermakna. Prinsip verifikasi ini menyatakan bahwa suatu proposisi adalah bermakna jika ia dapat diuji dengan pengalaman dan dapat diverifikasi dengan pengamatan (observasi) (Febrianty, 2020). Sebagai akibat dari prinsip ini filsafat tradisional haruslah ditolak karena ungkapanungkapannya melampaui pengalaman, termasuk dalam teologi dan metafisika pada umumnya, untuk lebih memahami prinsip verifikasi 'ala Carnap, menarik dilihat pembedaannya mengenai dua hukum dalam ilmu alam yaitu hukum empiris dan hukum teoretis, hukum empiris adalah hukum-hukum yang dapat dikonfirmasikan secara langsung dengan observasi-empiris, istilah "observable" sering digunakan untuk banyak fenomena yang secara langsung dapat diamati, dengan kata lain hukum empiris adalah hukum tentang yang kelihatan (observable) sementara hukum teoretis adalah hukum abstrak karena ia merupakan hipotesis. Adapun prinsip verifikasi itu merupakan pengandaian untuk melengkapi suatu kriteria, sehingga melalui kriteria tersebut dapat ditentukan apakah suatu kalimat mengandung makna atau tidak. Melalui prinsip ini tidak hanya kalimat yang teruji secara empirik saja yang dapat di analisis. dalam kerangka pemikiran semacam itu, filsafat ilmu pengetahuan mereka pandang semata-mata sebagi logika ilmu (The Logic of Science), yang ada dalam konteks logika ilmu hanyalah pengujian dan pembenaran (contexs of justification) ilmu pengetahuan yang bersangkutan. Mereka tidak peduli bagaimana ilmu pengetahuan tertentu itu muncul dan berkembang, mereka hanya merasa berkepentingan dengan pengujian susunan logis pernyataan-pernyataan ilmiah yang digunakan. Akibatnya filsafat ilmu dalam hal ini yang dimaksud logika ilmu kian jauh dari kenyataan ilmu pengetahuan yang terjadi sebenarnya, karena terlalu sibuk dengan apa yang seharusnya terjadi dalam ilmu pengetahuan. 
Fungsi filsafat menurut pandangan Ayer dalam (Na'im, 2021) itu melulu bersifat kritik. Kritik-kritik yang dilancarkan oleh filsafat itu memang berguna untuk mengantar kita kearah pintu gerbang ilmiah, namun itu bukan berarti filsafat merupakan suatu jenis "Super Sciences" (ilmu pengetahuan tertinggi), sebab tugas filsafat bukanlah menetapkan perandaian-perandaian bagi ilmu pengetahuan. Filsafat tidak mengandung tugas positif seperti yang di miliki ilmu-ilmu pengetahuan empirik.

\section{Konsep Falsifikasi}

Baik secara morfologis maupun semantik, perlu diuraikan bagaimana kata falsifikasi. Falsifikasi secara otomatis terkandung pada falsibilitas, kata falsify itu sendiri adalah kata kerja jadian yang terbentuk dari kata sifat false yang berarti salah dan ditambahkan kepadanya akhiran ify yang berarti menyebabkan 'menjadi'. Adapun falsification adalah bentuk kata benda dari kata kerja falsify, dengan demikian dapat dijelaskan bahwa kata sifat false diubah menjadi kata kerja dengan menambahkan akhiran ify sehingga menjadi falsify dan dibendakan dengan menambahkan akhiran action sehingga ia berubah menjadi falsification yang dilndonesiakan menjadi falsifikasi yang berarti 'hal pembuktian salah'.

Falsifikasi adalah suatu paham atau pemikiran yang berpendapat bahwa setiap teori yang dikemukakan manusia tidak akan seluruhnya sesuai dengan hasil observasi atau percobaan, dengan kata lain menurut pandangan falsifikasionisme ilmu dipandang sebagai satu set hipotesa yang bersifat tentatif untuk menggambarkan atau menghitung tingkah laku suatu aspek dunia atau universe. Jadi bagi mereka tidak ada suatu ilmu yang dibuat manusia bisa seratus persen sama apabila dikonfrontasi dengan hasil pengamatan dari kenyataan yang ada, dalam hal ini akan dikemukakan bagaimana seorang memperoleh pengetahuan dan selanjutnya pengetahauan tersebut dapat diputuskan ilmiah atau tidak ilmiah atau bagian dari true science atau bagian dari pseudoscinces. Menurut Popper dalam (Sofyan, 2020), manusia dalam memperoleh pengetahuan berdasarkan rasio yang ia miliki, pandangan ini sesuai dengan pandangan kaum rasionalis yang mengakui bahwa ada prinsip-prinsip dasar dunia tertentu yang diakui benar oleh manusia. Prinsip-prinsip pertama ini ber- sumber dalam budi manusia dan tidak dijabarkan pengalaman bahkan apa yang dialami dalam pengalaman emprisis bergantung pada prinsip-prinsip ini.

Sebagaimana disebutkan dalam uraian pendahuluan di atas bahwa meski Popper banyak berkenalan dengan gagasan-gagasan para filosuf yang tergabung di lingkaran Wina atau kaum positivism logis, namun ia tidak sependapat dengan gagasan mereka dalam bidang keilmuan terutama terkait dengan tiga ide utama, yakni masalah induksi, demarkasi, dan dunia ketiga. Proses induksi melalui observasi seperti inilah yang dipandang oleh kaum positivisme logis sebagai prinsip pembentukan ilmu atau pengetahuan. Proses induksi ini pula yang dijadikan untuk menciptakan hukum umum dan mutlak berdasarkan kriteria kebermaknaan (meaningfull) dan ketidakbermaknaan (meaningless). Selanjutnya proposisi-proporsi ilmu atau pengetahuan tersebut dipandang ilmiah, selain dibangun berdasar prinsip induksi melalui eksperimen atau observasi, juga jika dipandang memiliki kemampuan untuk menjelaskan dan meramalkan (Tanjung, 2020). Suatu pengetahuan adalah ilmiah, misalnya apabila seorang ahli astronomi dapat meramalkan kapan akan terjadi gerhana bulan berikutnya, atau bila seorang ahli fisika dapat menjelaskan mengapa titik mendidih air di tempat yang tinggi lebih rendah daripada di tempat yang normal (Chalmers, 1983). Secara sederhana, kebenaran atau keilmiahan suatu pengetahuan atau ilmu tersebut dapat digambarkan melalui skema berikut:

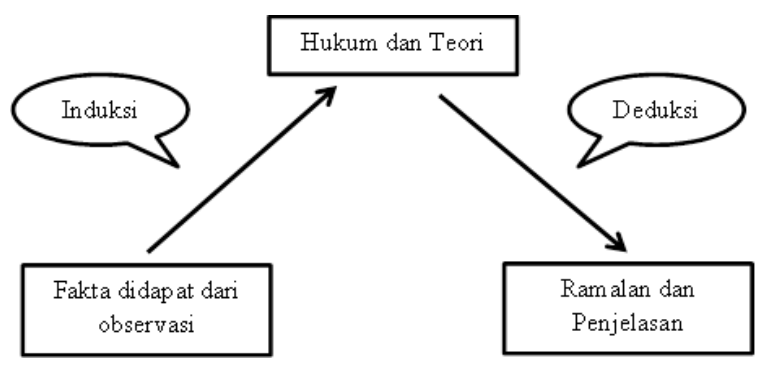

Gambar 1. Skema kebenaran ilmu Pengetahuan

Gambaran ilmu seperti yang digambarkan oleh kaum positivism logis, atau induktifis ini memberi penegasan yang tampak meyakinkan mengenai sifat dari suatu ilmu atau pengetahuan, yakni selain dayanya yang mampu meramalkan dan menjelaskan, juga adanya 
sifat keobyektifan dan reliabilitasnya yang lebih unggul dibanding jenis-jenis ilmu atau pengetahuan yang lain. Karena itu, wajar jika gagasan mereka ini begitu meyakinkan dan memiliki penganut yang begitu besar.Akan tetapi bagi Popper suatu teori atau proposisi ilmu atau pengetahuan tidak dipandang bersifat ilmiah hanya karena bisa dibuktikan kebenarannya melalui verifikasi seperti anggapan mereka, tetapi karena dapat diuji (testable) dengan melalui berbagai percobaan sistematis untuk menyangkalnya.

Secara sederhana falsifikasi Popper tersebut dalam digambarkan sebagai berikut :

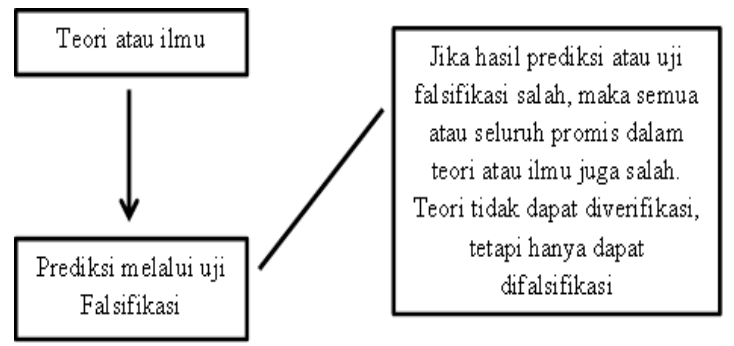

Gambar 2. Skema sederhana Falsifikasi Popper

Dari sinilah terlihat jelas bahwa keberadaan kritik atas teori atau proposisi-proposisi ilmu menjadi sebuah keniscayaan. Begitu juga setiap ilmuwan juga tidak dibenarkan alergi terhadap kritik, sebaliknya seorang ilmuwan yang sejati dirinya harus selalu berharap akan adanya kritik. Karena hanya dengan keberlangsungan adanya kritik seperti inilah ilmu pengetahuan akan terus mengalami perkembangan, Jika dalam pand-angan kaum Positivisme kriteria kebenaran suatu ilmu atau teori didasarkan pada kriteria dapat atau tidaknya dibenarkan secara empiris melalui konfirmasi atau verifikasi, maka tidak demikian halnya menurut Popper. Menurutnya ada beberapa kelemahan prinsip verifikasi yang dipakai kaum positivisme logis dalam menentukan perbedaan antara proposisi yang meaningfull dan meaningless.

\section{SIMPULAN DAN SARAN}

\section{A. Simpulan}

Berdasarkan pemaparan pada penelitian kritis terhadap epistemologi ilmu: konsep hypothetic-deductive, verifikasi, dan falsifikasi ini dapat disimpulkan bahwa:

1. Hypothetico-deductive method merupakan rangkaian langkah-langkah penelitian yang didasarkan atas sistem logika deduktif. Berbeda dengan penelitian yang didasarkan pada sistem logika induktif (grounded theory/research), maka dalam hypothetico deductive method, suatu penelitian empirik diawali oleh suatu proses deduktif yang berawal dari pembentukan kerangka teori, untuk melahirkan hipotesis-hipotesis sebagai jawaban sementara bagi masalah penelitian yang lebih lanjut akan diuji (melalui pencarian supporting empirical evidence) melalui suatu perangkat metodologi tertentu.

2. Verifikasi adalah teori filsafat logis yang mengatakan bahwa sumber pengetahuan itu berasal dari pengalaman yang kemudian diuji dengan metode verifikasi yang dibuktikan kebenarannya secara empiris.

3. Popper berpendapat bahwa suatu teori atau proposisi ilmu atau pengetahuan tidak dipandang bersifat ilmiah hanya karena bisa dibuktikan kebenarannya melalui verifikasi seperti anggapan mereka, tetapi karena dapat diuji (testable) dengan melalui berbagai percobaan sistematis untuk menyangkalnya. Bila suatu hipotesa atau suatu teori dapat bertahan melawan segala penyangkalan, maka kebenaran hipotesa atau teori tersebut semakin diperkokoh atau yang oleh Popper disebut corroboration.

\section{B. Saran}

Pembahasan terkait penelitian kritis terhadap epistemologi ilmu: konsep hypothetic-deductive, verifikasi, dan falsifikasi dalam penelitian ini masih sangat terbatas dan membutuhkan banyak masukan. Saran untuk penulis selanjutnya adalah mengkaji lebih dalam dan secara komprehensif terkait kritis terhadap epistemologi ilmu: konsep hypothetic-deductive, verifikasi dan falsifikasi.

\section{DAFTAR RUJUKAN}

Arifudin, 0. (2020). Psikologi Pendidikan (Tinjauan Teori Dan Praktis). Bandung: Widina Bhakti Persada.

Arifudin, 0. (2021). Implementasi Balanced Scorecard dalam Mewujudkan Pendidikan Tinggi World Class. Edumaspul: Jurnal Pendidikan, 5(2), 767-775. 
Arifudin, 0. (2018). Pengaruh Pelatihan Dan Motivasi Terhadap Produktivitas Kerja Tenaga Kependidikan STIT Rakeyan Santang Karawang. MEA (Manajemen, Ekonomi, \& Akuntansi), 2(3), 209-218.

Bahri, A. S. (2021). Pengantar Penelitian Pendidikan (Sebuah Tinjauan Teori dan Praktis). Bandung: Widina Bhakti Persada.

Bairizki, A. (2021). Manajemen Perubahan. Bandung : Widina Bhakti Persada.

Braithwaite. (1960). Braithwaite, Richard Bevan, Scientific Explanation: A Study of the Function of Theory, Probability and Law in Science, (Cambridge University Press, 1960),. London: Cambridge University Press.

Carnap. (1966). The Rejection of Metaphysics. New York: The Free Press.

Chalmers. (1983). What is This Thing Called Science (Apa itu yang Dinamakan Ilmu), terj. Redaksi hasta Karya. Jakarta : Hasta Karya.

Darmawan, I. P. A. (2021). Total Quality Management Dalam Dunia Pendidikan" Model, Teknik Dan Impementasi". Bandung: Widina Bhakti Persada Bandung.

Darsono. (2010). Filsafat Ilmu Pendidikan. Jakarta : Nusantara Consulting.

Fatira, M. (2021). Pembelajaran Digital. Bandung: Widina Bhakti Persada.

Febrianty, F. (2020). Kepemimpinan \& Prilaku Organisasi Konsep Dan Perkembangan. Bandung: Widina Bhakti Persada.

Hanafiah, H. (2021). Pelatihan Software Mendeley Dalam Peningkatan Kualitas Artikel Ilmiah Bagi Mahasiswa. Jurnal Karya Abdi Masyarakat, 5(2), 213-220.

Hasbi, I. (2021). Administrasi Pendidikan (Tinjauan Teori Dan Praktik). Bandung: Widina Bhakti Persada.

Irwansyah, R. (2021). Perkembangan Peserta Didik. Bandung: Widina Bhakti Persada.
Jujun. (2007). Filsafat Ilmu sebuah Pengantar Populer. Jakarta: Pancaraninta.

Mayasari, A. (2021). Implementasi Sistem Informasi Manajemen Akademik Berbasis Teknologi Informasi dalam Meningkatkan Mutu Pelayanan Pembelajaran di SMK. JIIPJurnal Ilmiah Ilmu Pendidikan, 4(5), 340345. https://doi.org/10.54371/jiip.v4i5.277

Mundiri. (2000). Logika. Jakarta: Raja Grafindo Persada.

Muslih. (2014). Pengantar Ilmu Filsafat. Ponorogo : Darussaam University Press.

Mustansyir. (2001). Filsafat Analitik. Bandung: Pustaka Setia.

Na'im, Z. (2021). Manajemen Pendidikan Islam. Bandung: Widina Bhakti Persada.

Nasser, A. A. (2021). Sistem Penerimaan Siswa Baru Berbasis Web Dalam Meningkatkan Mutu Siswa Di Era Pandemi. Biormatika: Jurnal Ilmiah Fakultas Keguruan Dan Ilmu Pendidikan, 7(1), 100-109.

Popper. (1986). Objective Knowledge, A Revolutionary Approach. New York: Clarden Press Oxford.

Popper. (2008). The Logic of Scientific Discovery (Logika Penemuan Ilmiah), terj. Saut Pasaribu \& Aji Sastrowardoyo. Yogyakarta: Pustaka Pelajar.

Rahayu, Y. N. (2020). Program Linier (Teori Dan Aplikasi). Bandung : Widina Bhakti Persada.

Sofyan, Y. (2020). Peranan Konseling Dosen Wali Dalam Meningkatkan Motivasi Belajar Mahasiswa Di Perguruan Tinggi Swasta Wilayah LLDIKTI IV. Jurnal Bimbingan Dan Konseling Islam, 10(2), 237-242.

Siregar, R. T. (2021). Komunikasi Organisasi. Bandung: Widina Bhakti Persada.

Sugiyono. (2015). Metode Penelitian Pendidikan (Pendekatan Kuantitatif,. Kualitatif dan $R \& D)$. Bandung : CV. Alfabeta. 
Sumantri. (2005). Filsafat ilmu, sebuah pengantar popular. Jakarta: Sinar harapan.

Supriani, Y. (2022). Peran Manajemen Kepemimpinan dalam Pengelolaan Lembaga Pendidikan Islam. JIIP-Jurnal Ilmiah Ilmu Pendidikan, 5(1), 332-338.

Tanjung, R. (2020). Pengaruh Penilaian Diri Dan Efikasi Diri Terhadap Kepuasan Kerja Serta Implikasinya Terhadap Kinerja Guru. Jurnal Ilmiah MEA (Manajemen, Ekonomi, Dan Akuntansi), 4(1), 380-391.
Tanjung, R. (2022). Manajemen Penyelenggaraan Pendidikan Inklusi pada Lembaga Pendidikan Islam. JIIP-Jurnal Ilmiah Ilmu Pendidikan, 5(1), 339-348.

Taryadi. (1991). Epistemologi Pemecahan Masalah Menurut Karl Popper. Jakarta: PT. Gramedia Pustaka Utama.

Ulfah, U. (2022). Kepemimpinan Pendidikan di Era Disrupsi. JIIP-Jurnal Ilmiah Ilmu Pendidikan, 5(1), 153-161. 